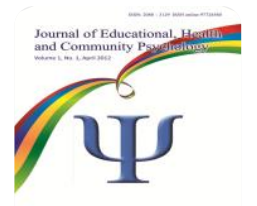

\title{
Intolerance of Uncertainty among Indonesian Workers During Covid- 19 Pandemic
}

\author{
Afinnisa Rasyida \\ Psychology Department of Universitas Surabaya in Surabaya, Indonesia \\ afinnisarasyida@staff.ubaya.ac.id \\ Maria Nugraheni Mardi Rahayu \\ Psychology Department of Universitas Kristen Satya Wacana in Salatiga, Indonesia \\ nugraheni.maria@uksw.edu \\ Nindya Putri Aprodita \\ Psychology Department of Universitas Bunda Mulia in Tangerang, Indonesia \\ naprodita@bundamulia.ac.id
}

\begin{abstract}
This research aims to describe the Intolerance of uncertainty (IU) among Indonesian workers during COVID-19 pandemic. A total of 351 workers in Java (64 males, 287 females) were involved as a participant. IU was measured using the Indonesian version of IUS-27. This study showed that most (41.9\%) of the participants had a low level of IU; meanwhile, 36.8\% of the participant had a high level of IU. The result of the difference test showed that there was a difference in IU between males and females ( $p=0.011)$ and between participants in the upper, middle, and lower SES $(p=0.018)$. These findings show that females and people with low SES had a higher IU than other groups. These findings can be used as a reference by companies to identify and take preventive action toward workers who possessed a higher risk of developing a higher IU, especially in a situation full of uncertainty.
\end{abstract}

Keywords: Intolerance of uncertainty, workers, COVID-19 pandemic

Received 7 November 202I/Accepted 28 February 2022 @Author all rights reserved

\section{Introduction}

COVID-19 pandemic, which has been occurring for more than a year, results in uncertainty towards people in Indonesia. By 28 March 202I, the data from the Map of COVID-19 Cases (Satuan Tugas Penanganan Covid 19, 202I) showed that cumulatively, the number of cases had reached I,496,085. Total positive cases in the 19-30 years old age group are $24.75 \%$, and $31-45$ years old age group is $30.43 \%$. 

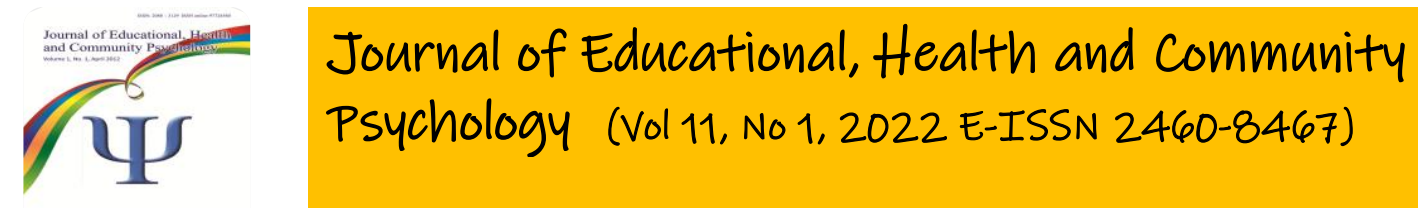

Rasyida, Rahayu, Aprodita.

This data showed that the productive age group (19-45 years old) is the most vulnerable to virus infections.

In order to suppress the spread of COVID-19, the Indonesian government took a policy in the form of social restrictions on the community called PSBB (Large-Scale Social Restrictions), especially for Java Island, which showed a much higher case rate compared to other regions. Through the PSBB policy, the government requires residents' activities such as going to school and working are to be done from home, restrictions on religious activities, restrictions on activities in public places/facilities, restrictions on social and cultural activities, restrictions on transportation modes, and restrictions on other activities related explicitly to defense and security aspects (Satuan Tugas Penanganan Covid 19, 2020). In addition, the community is also expected to adjust to the new normal lifestyle. This raised challenges in various fields, such as the economy. Data from the Ministry of Manpower in April 2020 noted that workers affected by COVID- 19 reached 2,084,593 workers from the formal and informal sectors from II 6,370 companies. Furthermore, the Minister of Manpower stated that the number of companies and formal workers laid off was $1,304,777$ out of 43,690 companies. At the same time, formal workers who were laid off were 24I,43I workers from 4I,236 companies (Kemnaker, 2020). Due to many workers being laid off from the pandemic, more and more people are left unemployed with no income and financial instability.

Not enough information about the impact of a pandemic on the different aspects of daily life, such as the economy, health, and duration of the restriction, has caused great uncertainty (Zhuo et al., 202I). In addition, economic conditions affected by the pandemic can also create financial and career uncertainty for workers. On the other hand, although not all workers will experience the threat of layoffs and reduced income, this pandemic also creates other uncertainties, such as fears of exposure and limited mobilization. Work has a function that is directly related to psychological health and individual selfesteem; therefore, job insecurity will have implications for one's identity, faith and self-efficacy, selfconfidence, and social support systems (Godinic, Obrenovic, \& Khudaykulov, 2019). Uncertainty conditions are potentially causing depression, fear, worry, and anxiety in individuals (Aprodita, 202I; Gu, 

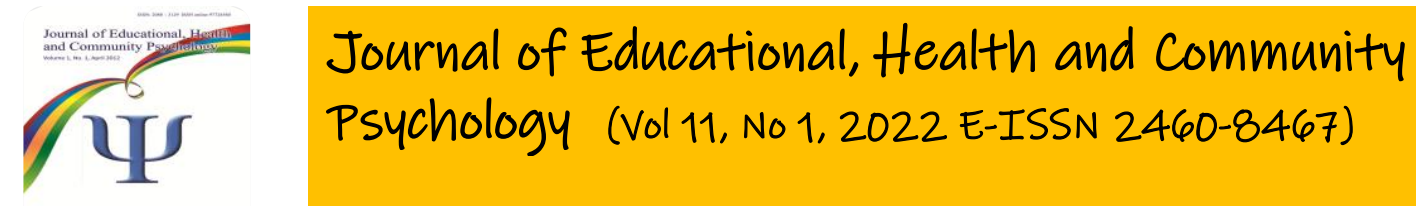

Rasyida, Rahayu, Aprodita.

Gu, Lei, \& Li, 2020). The impact will be more significant on an individual's mental health when individuals cannot tolerate the uncertain situation experienced in a pandemic situation such as right now.

An individual's inability to tolerate a situation of uncertainty is known as Intolerance of uncertainty (IU). $\mathrm{IU}$ is a major component of excessive worrying (in the cognitive-behavioral model) (Dugas, Gagnon, Ladouceur, \& Freeston, 1998). IU can be understood as to how a person perceives information in an uncertain situation and responds to this information with a series of cognitive, emotional, and behavioral reactions (Dugas, Gosselin, \& Ladouceur, 200I). Furthermore, Dugas et al. (200I) explain that IU is defined as an excessive individual tendency to assume that the possibility of an adverse event occurring is unacceptable, no matter how little the possibility is.

Individuals with higher uncertainty intolerance tend to exaggerate threats and perceive problems more than they do (Valle et al., 2020; Pepperdine, Lomax, \& Freeston, 2018; Taha, Matheson, Cronin, \& Anisman, 20I4). Previous research has shown that IU is associated with concern in clinical and nonclinical populations. Ladouceur, Gosselin, and Dugas (2000) showed that experimentally increasing Intolerance to uncertainty causes increased concern. Intolerance to uncertainty has been suggested as a cognitive susceptibility factor for worry and GAD (Koerner \& Dugas, in Sexton \& Dugas, 2009). If not anticipated, high levels of $\mathrm{IU}$ in individuals can be at risk of developing more serious psychological disorders, especially anxiety. Measurement of IU can be used as a way for early detection of this trend.

Previous studies on IU in Indonesia are still limited and usually target the student population and students with specific problems in education and social relations with peers (Yuniardi, 2020; Rahmadiani, Hartatik, \& Latipun, 2019). Research targeting workers has not been carried out, even though workers have many challenges that can threaten the security and stability of life in various areas. In addition, research that has raised IU in the context of the COVID-19 pandemic has not been widely carried out even though the COVID-19 pandemic has had an impact that has certain characteristics; therefore, it is crucial to investigate. 

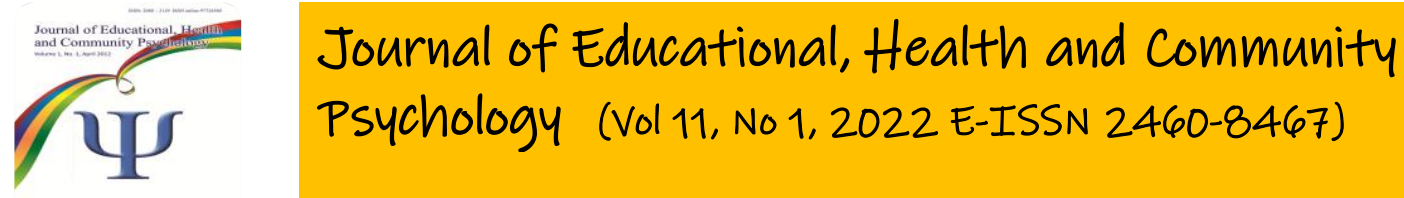

Rasyida,
Rahayu,
Aprodita.

This study aimed to describe the level of workers' IU during the COVID-I9 pandemic, especially in Java. By knowing the description of the workers' IU level during the COVID-I9 pandemic, it is expected that workers will be more aware of the existence of psychological conditions that are at risk of developing into more serious psychological disorders in dealing with changing situations. Likewise, the company can take policies to follow up on this problem.

\section{Method}

\section{Research Design}

This research used a quantitative approach with a single variable: Intolerance of uncertainty (IU).

\section{Participants}

The participants in this research are Indonesian workers. As many as 35I participants were involved in this research. The demographic details are served in Table I below.

\section{Measures}

This study refers to the Intolerance of Uncertainty Scale (Buhr \& Dugas, 2002), which was translated into Bahasa Indonesia by the researcher. Validity and reliability were measured with corrected item-total correlation $(r=0.297-0.8 I 4)$ and internal consistency respectively $(\alpha=0.95 \mathrm{I})$. The IUS questionnaire contains 27 items related to a person's reaction to uncertainty, ambiguous situations, and the future. This questionnaire uses a Likert scale with a 5-point range ranging from "strongly disagree" to "strongly agree." The scores obtained ranged from 27 to 135 points. Examples of items from IUS are "uncertainty makes life intolerable," "I always want to know what the future has in store for me," and "uncertainty keeps me from living a full life." 
Table I

The Data of Participants' Demography

\begin{tabular}{|c|c|c|c|}
\hline Category & & Total & $\%$ \\
\hline \multirow{2}{*}{ Gender } & Male & 64 & $18.23 \%$ \\
\hline & Female & 287 & $81.77 \%$ \\
\hline \multirow{3}{*}{ Marital Status } & Single & 256 & $72.93 \%$ \\
\hline & Married & 86 & $24.50 \%$ \\
\hline & Widowed & 9 & $2.56 \%$ \\
\hline \multirow{4}{*}{ Occupation } & $\begin{array}{l}\text { State-owned Enterprises } \\
\text { Workers }\end{array}$ & 10 & $2.85 \%$ \\
\hline & Civil Workers & 33 & $9.40 \%$ \\
\hline & Private Workers & 247 & $70.37 \%$ \\
\hline & Entrepreneurs & 61 & $17.38 \%$ \\
\hline \multirow{4}{*}{ Latest Education } & High School & 23 & $6.55 \%$ \\
\hline & Diploma & 30 & $8.55 \%$ \\
\hline & Bachelor & 234 & $66.67 \%$ \\
\hline & Magister & 64 & $18.23 \%$ \\
\hline \multirow{3}{*}{ Socio-Economic Status } & Lower & 18 & $5.13 \%$ \\
\hline & Middle & 331 & $94.30 \%$ \\
\hline & Higher & 4 & $1.14 \%$ \\
\hline \multirow{6}{*}{ Residence } & Banten & 35 & $9.97 \%$ \\
\hline & Jakarta & 85 & $24.22 \%$ \\
\hline & West Java & 94 & $26.78 \%$ \\
\hline & Central Java & 58 & $16.52 \%$ \\
\hline & East Java & 58 & $16.52 \%$ \\
\hline & Yogyakarta & 21 & $5.98 \%$ \\
\hline
\end{tabular}



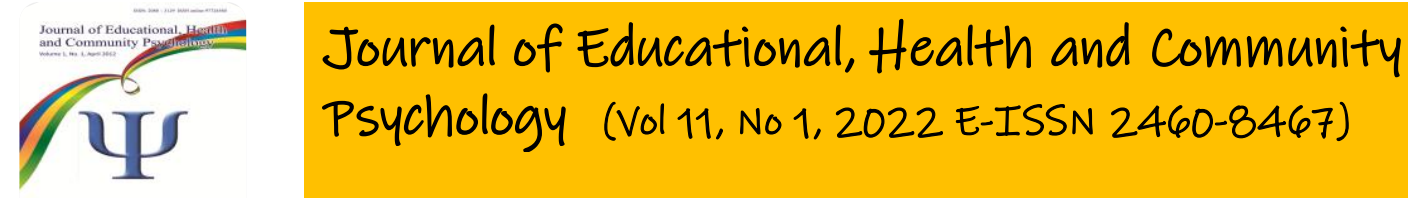

Rasyida, Rahayu, Aprodita.

\section{Procedures}

Research participants were recruited through invitations from the authors to colleagues and acquaintances forwarded through social media such as Instagram, Twitter, Linkedln, and WhatsApp. A written explanation of the purpose of the study was provided both in the invitation and at the beginning of the questionnaire form. After that, participants were asked to indicate their willingness to participate by filling out informed consent and continuing the process to complete demographic data and the IUS27 scale.

\section{Statistical Analysis}

This study used descriptive statistical analysis to describe the level of Intolerance towards uncertainty that employees have in early adulthood. To describe the IU level of participants, the researcher categorized the data using statistics from measuring instruments (hypothetical statistics). Widhiarso (20l4) explained that the mean and standard deviation used as material for compiling category points were obtained from measuring instruments with this technique. The researcher then described how many participants were amongst very high, high, low, and very low categories. In addition, this study also examined differences in IU levels among male and female employees and employees with upper, middle, and lower socio-economic status. The researcher used statistical analysis t-test and one-way ANOVA to find out this difference. In addition, the researchers also conducted a cross-tabulation test between IU and supporting data in the form of gender, socio-economic status, residential status, marital status, latest education, and occupation. This was done to see the distribution of IU score categories in each group.

\section{Result}

Based on the score categorization, the IU scores of the participants in this study were mostly in the low category of $41.9 \%$, followed by the high category of $36.8 \%$. In more detail, the results are presented in Table 2. 
Table 2

The Level of IUS in Employees

\begin{tabular}{llllll}
\hline & Frequency & Percentage & $\begin{array}{l}\text { Valid } \\
\text { Percentage }\end{array}$ & $\begin{array}{l}\text { Cumulative } \\
\text { Percentage }\end{array}$ \\
\hline Valid & Very Low & 31 & 8.8 & 8.8 & 8.8 \\
& Low & 147 & 41.9 & 41.9 & 50.7 \\
& High & 129 & 36.8 & 36.8 & 87.5 \\
& Very High & 44 & 12.5 & 12.5 & 100.0 \\
& Total & 351 & 100 & 100 & \\
\hline
\end{tabular}

Table 3

Descriptive Statistics

\begin{tabular}{llllll}
\hline & $N$ & Minimum & Maximum & Mean & Std. Deviation \\
\hline Total & 351 & 32 & 134 & 81.8 & 20.9 \\
Valid N & 351 & & & & \\
\hline
\end{tabular}

The comparison between the two mean values shows that the empirical mean $(X=81.8)$ is slightly higher than the theoretical mean $(\mathrm{u}=8 \mathrm{I})$. This indicates that the IUS of participants in this study tends to be high. Meanwhile, the comparison between the two standard deviation values shows that the empirical standard deviation $(S D=20.9)$ is higher than the theoretical standard deviation $(S D=18)$. this shows that the IUS scores in this study participants have a high variation. 


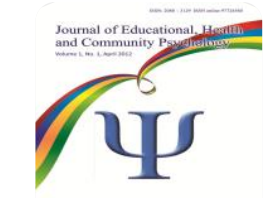

\section{Journal of Educational, Health and Community \\ Psychology (Vol 11, No 1, 2022 E-ISSN 2460-8467)}

Rasyida,

Rahayu,

Aprodita.

Table 4

Gender group difference test

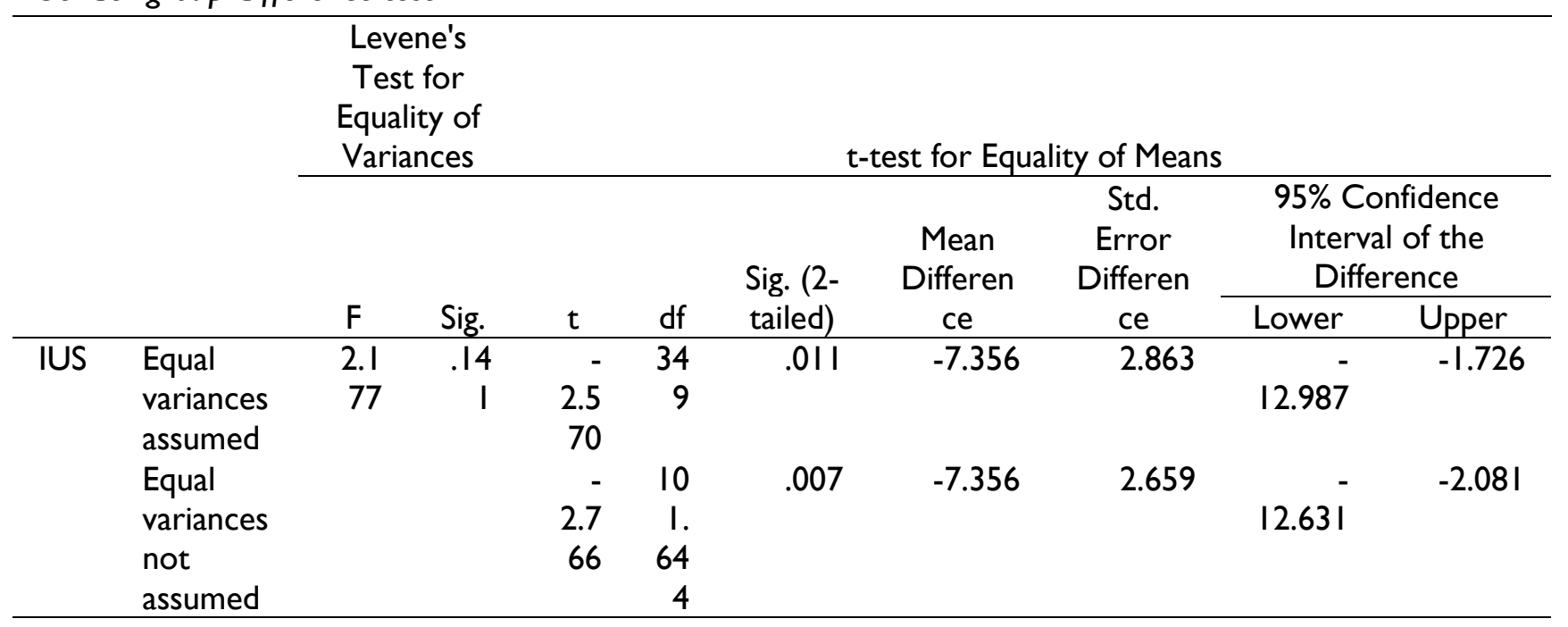

Based on the results of the statistical tests shown in Table 4, it was concluded that there was a significant difference in the IU scores of the participants based on gender $(t(349)=-2.570, p=0.01 \mathrm{I})$. In other words, there is a significant difference between male and female IU scores, with the female having the higher scores.

Table 5

Difference Test of Socio-Economic Status

\begin{tabular}{lrrrrr} 
& \multicolumn{1}{l}{$\begin{array}{l}\text { Sum of } \\
\text { Squares }\end{array}$} & df & Mean Square & F & \multicolumn{1}{c}{ Sig. } \\
\hline Between Groups & 4399.769 & 2 & 2199.884 & 5.169 & .006 \\
Within Groups & 148094.339 & 348 & 425.558 & & \\
Total & 152494.108 & 350 & & & \\
\hline
\end{tabular}




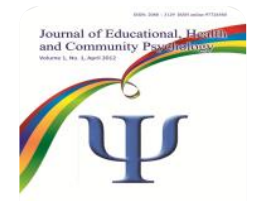

\section{Journal of Educational, Health and Community Psychology (Vol 11, No 1, 2022 E-ISSN 2460-8467)}

Rasyida, Rahayu, Aprodita.

The statistical tests shown in Table 5 concluded that there was a significant difference in the IU scores of the participants based on socio-economic status groups $(F(2)=5.169, p=0.006)$. There is a significant difference between the IU scores of participants with lower, middle, and upper socio-economic status.

Table 6

Post-Hoc Test Result

\begin{tabular}{|c|c|c|c|c|c|c|c|}
\hline & \multirow[b]{2}{*}{$\begin{array}{l}\text { (I) Socio- } \\
\text { Economic } \\
\text { Status }\end{array}$} & \multirow[b]{2}{*}{$\begin{array}{l}\text { (J) Socio- } \\
\text { Economic } \\
\text { Status }\end{array}$} & \multirow{2}{*}{$\begin{array}{c}\text { Mean } \\
\text { Differe } \\
\text { nce (I- } \\
\text { J) }\end{array}$} & \multirow[b]{2}{*}{$\begin{array}{l}\text { Std. } \\
\text { Error }\end{array}$} & \multirow[b]{2}{*}{ Sig. } & \multicolumn{2}{|c|}{$\begin{array}{l}\text { 95\% Confidence } \\
\text { Interval }\end{array}$} \\
\hline & & & & & & $\begin{array}{l}\text { Lower } \\
\text { Bound }\end{array}$ & $\begin{array}{l}\text { Upper } \\
\text { Bound }\end{array}$ \\
\hline \multirow[t]{6}{*}{ Bonferroni } & Lower & Middle & $16.507^{*}$ & 5.280 & .006 & 3.80 & 29.21 \\
\hline & & Higher & 7.938 & 11.532 & 1.000 & -19.80 & 35.68 \\
\hline & Middle & Lower & $16.507^{-}$ & 5.280 & .006 & -29.21 & -3.80 \\
\hline & & Higher & -8.569 & 10.377 & 1.000 & -33.53 & 16.39 \\
\hline & Higher & Lower & -7.937 & 11.532 & 1.000 & -35.68 & 19.80 \\
\hline & & Middle & 8.569 & 10.377 & 1.000 & -16.39 & 33.53 \\
\hline
\end{tabular}

The post-doc test (Table 6) result showed that the groups which had a difference in the average IU were the lower and middle socio-economic status groups ( $p=0.006,95 \% \mathrm{Cl}[3.80,29.21])$. 


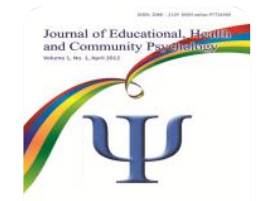

Journal of Educational, Health and Community

Psychology (Vol 11, No 1, 2022 E-ISSN 2460-8467)

Rasyida,

Rahayu,

Aprodita.

Table 7

Cross-Tabulations of Gender and IU

\begin{tabular}{lllrrrrr}
\hline & & \multicolumn{2}{c}{ IU } & \multicolumn{2}{c}{ Total } \\
\cline { 3 - 7 } & & & Very Low & \multicolumn{1}{c}{ Low } & High & Very High & \multicolumn{2}{c}{ Tow } \\
\hline Gender & Male & Frequency & 8 & 32 & 21 & 3 & 64 \\
& & $\%$ & $12.5 \%$ & $50.0 \%$ & $32.8 \%$ & $4.7 \%$ & $100.0 \%$ \\
& Female & Frequency & 23 & 115 & 108 & 41 & 287 \\
& & $\%$ & $8.0 \%$ & $40.1 \%$ & $37.6 \%$ & $14.3 \%$ & $100.0 \%$ \\
Total & & Frequency & 31 & 147 & 129 & 44 & 351 \\
& & $\%$ & $8.8 \%$ & $41.9 \%$ & $36.8 \%$ & $12.5 \%$ & $100.0 \%$ \\
\hline
\end{tabular}

Cross-Tabulations' IU Levels and gender results showed that $50 \%$ of males had low IU levels. The low IU rate is also owned mainly by females, as many as $40.1 \%$. Females had a greater percentage in the higher IU level category (37.6\%) than males (32.8\%).

Table 8

Cross-Tabulations of Socio-Economic Status and IU

\begin{tabular}{|c|c|c|c|c|c|c|c|}
\hline & & & \multicolumn{4}{|c|}{ IU } & \multirow[b]{2}{*}{ Total } \\
\hline & & & Very Low & Low & High & Very High & \\
\hline Socio- & Lower & Frequency & 0 & 4 & 8 & 4 & 16 \\
\hline Econo & & $\%$ & $0.0 \%$ & $25.0 \%$ & $50.0 \%$ & $25.0 \%$ & $100.0 \%$ \\
\hline mic & Middle & Frequency & 31 & $|4|$ & 120 & 39 & 331 \\
\hline \multirow[t]{3}{*}{ Status } & & $\%$ & $9.4 \%$ & $42.6 \%$ & $36.3 \%$ & $11.8 \%$ & $100.0 \%$ \\
\hline & Higher & Frequency & 0 & 2 & I & I & 4 \\
\hline & & $\%$ & $0.0 \%$ & $50.0 \%$ & $25.0 \%$ & $25.0 \%$ & $100.0 \%$ \\
\hline \multirow[t]{2}{*}{ Total } & & Frequency & 31 & 147 & 129 & 44 & $35 I$ \\
\hline & & $\%$ & $8.8 \%$ & $41.9 \%$ & $36.8 \%$ & $12.5 \%$ & $100.0 \%$ \\
\hline
\end{tabular}

Cross-tabulations results of IU and socio-economic status showed that $50 \%$ of participants with upper socio-economic status had low IU levels. Meanwhile, $42.6 \%$ of participants with middle socio-economic status had low IU levels. As many as $50 \%$ of participants with lower socio-economic status have high IU levels. 


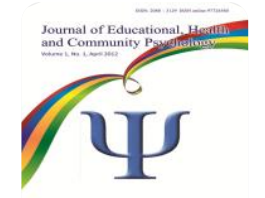

\section{Journal of Educational, Health and Community \\ Psychology (Vol 11, No 1, 2022 E-ISSN 2460-8467)}

Rasyida,

Rahayu,

Aprodita.

Table 9

Cross-Tabulations of Residence and IU

\begin{tabular}{|c|c|c|c|c|c|c|c|}
\hline & & & \multicolumn{4}{|c|}{ IU } & \multirow[t]{2}{*}{ Total } \\
\hline & & & Very Low & Low & High & $\begin{array}{l}\text { Very } \\
\text { High }\end{array}$ & \\
\hline \multirow{12}{*}{$\begin{array}{l}\text { Reside } \\
\text { ntial } \\
\text { Status }\end{array}$} & Banten & Frequency & 3 & 13 & 16 & 3 & 35 \\
\hline & & $\%$ & $8.6 \%$ & $37.1 \%$ & $45.7 \%$ & $8.6 \%$ & $100.0 \%$ \\
\hline & Jakarta & Frequency & 7 & 31 & 35 & 12 & 85 \\
\hline & & $\%$ & $8.2 \%$ & $36.5 \%$ & $41.2 \%$ & $14.1 \%$ & $100.0 \%$ \\
\hline & West Java & Frequency & 9 & 45 & 26 & 14 & 94 \\
\hline & & $\%$ & $9.6 \%$ & $47.9 \%$ & $27.7 \%$ & $14.9 \%$ & $100.0 \%$ \\
\hline & Central Java & Frequency & 4 & 24 & 24 & 6 & 58 \\
\hline & & $\%$ & $6.9 \%$ & $41.4 \%$ & $41.4 \%$ & $10.3 \%$ & $100.0 \%$ \\
\hline & East Java & Frequency & 7 & 25 & 18 & 8 & 58 \\
\hline & & $\%$ & $12.1 \%$ & $43.1 \%$ & $31.0 \%$ & $13.8 \%$ & $100.0 \%$ \\
\hline & Yogyakarta & Frequency & I & 9 & 10 & I & 21 \\
\hline & & $\%$ & $4.8 \%$ & $42.9 \%$ & $47.6 \%$ & $4.8 \%$ & $100.0 \%$ \\
\hline \multirow[t]{2}{*}{ Total } & & Frequency & 31 & 147 & 129 & 44 & 351 \\
\hline & & $\%$ & $8.8 \%$ & $41.9 \%$ & $36.8 \%$ & $12.5 \%$ & $100.0 \%$ \\
\hline
\end{tabular}

Based on the table above, it is known that most of the participants who live in Banten (45.7\%), Jakarta (4I.2\%), and Yogyakarta (47.6\%) have IU in the high category. Meanwhile, most of the participants who live in West Java (47.9\%) and East Java (43.I) have IU in the low category. Most of the participants who live in Central Java have IU in the low (4I.4\%) and high (4I.4\%).

Table 10 Cross-Tabulations of Marital Status and IU

\begin{tabular}{|c|c|c|c|c|c|c|c|}
\hline & & & \multicolumn{4}{|c|}{ IU } & \multirow[t]{2}{*}{ Total } \\
\hline & & & Very Low & Low & High & $\begin{array}{l}\text { Very } \\
\text { High }\end{array}$ & \\
\hline Marital & Single & Frequency & 20 & 97 & 105 & 34 & 256 \\
\hline \multirow[t]{5}{*}{ Status } & & $\%$ & $7.8 \%$ & $37.9 \%$ & $41.0 \%$ & $13.3 \%$ & $100.0 \%$ \\
\hline & Married & Frequency & 10 & 48 & 23 & 5 & 86 \\
\hline & & $\%$ & $11.6 \%$ & $55.8 \%$ & $26.7 \%$ & $5.8 \%$ & $100.0 \%$ \\
\hline & Widowed & Frequency & I & 2 & I & 5 & 9 \\
\hline & & $\%$ & $11.1 \%$ & $22.2 \%$ & $11.1 \%$ & $55.6 \%$ & $100.0 \%$ \\
\hline \multirow[t]{2}{*}{ Total } & & Frequency & 31 & 147 & 129 & 44 & 351 \\
\hline & & $\%$ & $8.8 \%$ & $41.9 \%$ & $36.8 \%$ & $12.5 \%$ & $100.0 \%$ \\
\hline
\end{tabular}


Based on cross-tabulations results, as many as $41 \%$ of single participants have IU in the high category. In addition, $55.8 \%$ of participants with married status have IU in the low category and $55.6 \%$ of participants who are widows had IU in the very high category.

Table II

Cross-Tabulations of Latest Education and IU

\begin{tabular}{|c|c|c|c|c|c|c|c|}
\hline & & & \multicolumn{4}{|c|}{ IU } & \multirow[t]{3}{*}{ Total } \\
\hline & & & \multicolumn{3}{|l|}{ Very } & \multirow{2}{*}{$\begin{array}{l}\text { Very } \\
\text { High }\end{array}$} & \\
\hline & & & Low & Low & High & & \\
\hline Latest & High & Frequency & 0 & 12 & 7 & 4 & 23 \\
\hline \multirow[t]{7}{*}{ Education } & School & $\%$ & $0.0 \%$ & $52.2 \%$ & $30.4 \%$ & $17.4 \%$ & $100.0 \%$ \\
\hline & Diploma & Frequency & 3 & 15 & 7 & 5 & 30 \\
\hline & & $\%$ & $10.0 \%$ & $50.0 \%$ & $23.3 \%$ & $16.7 \%$ & $100.0 \%$ \\
\hline & Bachelor & Frequency & 16 & 88 & 101 & 29 & 234 \\
\hline & & $\%$ & $6.8 \%$ & $37.6 \%$ & $43.2 \%$ & $12.4 \%$ & $100.0 \%$ \\
\hline & Magister & Frequency & 12 & 32 & 14 & 6 & 64 \\
\hline & & $\%$ & $18.8 \%$ & $50.0 \%$ & $21.9 \%$ & $9.4 \%$ & $100.0 \%$ \\
\hline \multirow[t]{2}{*}{ Total } & & Frequency & 31 & 147 & 129 & 44 & 351 \\
\hline & & $\%$ & $8.8 \%$ & $41.9 \%$ & $36.8 \%$ & $12.5 \%$ & $100.0 \%$ \\
\hline
\end{tabular}

In terms of education, most of the participants with a high school education (52.2\%), Diploma (50\%), and Masters (50\%) had IU in the low category. On the other hand, most of the participants with a bachelor's degree (43.2\%) had a high IU.

Table 12

Cross-Tabulations of Occupation and IU

\begin{tabular}{|c|c|c|c|c|c|c|c|}
\hline & & & \multicolumn{4}{|c|}{$\mathrm{IU}$} & \multirow[t]{2}{*}{ Total } \\
\hline & & & Very Low & Low & High & Very High & \\
\hline \multirow[t]{8}{*}{ Occupation } & State-owned & Frequency & 0 & 2 & 8 & 0 & 10 \\
\hline & $\begin{array}{l}\text { Enterprises } \\
\text { Workers }\end{array}$ & $\%$ & $0.0 \%$ & $20.0 \%$ & $80.0 \%$ & $0.0 \%$ & $100.0 \%$ \\
\hline & Civil Workers & Frequency & 5 & 15 & 9 & 4 & 33 \\
\hline & & $\%$ & $15.2 \%$ & $45.5 \%$ & $27.3 \%$ & $12.1 \%$ & $100.0 \%$ \\
\hline & Private & Frequency & 20 & 107 & 90 & 30 & 247 \\
\hline & Workers & $\%$ & $8.1 \%$ & $43.3 \%$ & $36.4 \%$ & $12.1 \%$ & $100.0 \%$ \\
\hline & Entrepreneurs & Frequency & 6 & 23 & 22 & 10 & 61 \\
\hline & & $\%$ & $9.8 \%$ & $37.7 \%$ & $36.1 \%$ & $16.4 \%$ & $100.0 \%$ \\
\hline \multirow[t]{2}{*}{ Total } & & Frequency & 31 & 147 & 129 & 44 & 351 \\
\hline & & $\%$ & $8.8 \%$ & $41.9 \%$ & $36.8 \%$ & $12.5 \%$ & $100.0 \%$ \\
\hline
\end{tabular}



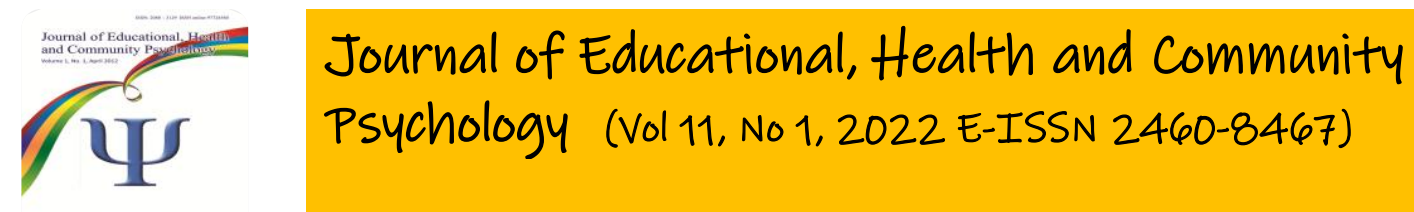

Rasyida, Rahayu, Aprodita.

\section{Discussion}

The purpose of this study is to describe the level of Intolerance to the uncertainty that workers/employees have during the COVID-19 pandemic. Based on the study results, it can be concluded that workers' level of Intolerance of uncertainty in this study during the COVID-19 pandemic tends to be low (4I.9\%). This shows that employees who are respondents in this study consider that the possibility of an adverse event in life is normal. In addition, uncertain situations and raising doubts can still be tolerated and do not lead to maladaptive behavior. In the context of a pandemic, the potential for job loss is one of the threats faced by participants (Ministry of Manpower, 2020).

On the other hand, the perception of whether the risk is a big threat or not depends not only on the level of IU but also on the individual's capability to deal with the uncertainty associated with job loss and all its effects (Blanuša, Barzut, \& Knežević, 202I). It can be seen from the demographic data of the participants in this study that most of the participants are individuals from a middle socio-economic background (effluent). This relatively affluent financial condition makes them not worry excessively during a pandemic. Previous research has shown that low IU levels correlate with low levels of fear of COVID19, depression, stress, and anxiety, as well as high positivity (Bakioğlu, Korkmaz, \& Ercan, 2020).

This study also showed that some respondents indicate a high level of IU (36.8\%) and very high (I2.5\%). Respondents who have a high level of IU consider that the possibility of an adverse event in life is difficult to tolerate. Worrying about uncertainty in life triggers negative feelings in individuals and can cause maladaptive behavior. On the other hand, respondents who have a very high level of IU consider that the possibility of an adverse event in life cannot be tolerated. Moreover, this threat is felt by the individual and others; therefore, the individual loses their social capital (Asmundson, Paluszek, Landry, Rachor, McKay \& Taylor, 2020). This will be increasingly felt by individuals, especially in conditions of social isolation or PSBB. Worrying about uncertainty in life can trigger negative feelings that are very disturbing to individuals and have a high potential to cause maladaptive behavior. Several studies have shown that high IU levels are predictors of depression (Saulnier, 2019; Valle et al., 2020), anxiety (Chen, Yao, \& Qian, 2018; Nekic \& Mamic, 2019), and uncertainty distress (Freeston, Tiplady, Mawn, Bottesi \& Thwaites, 

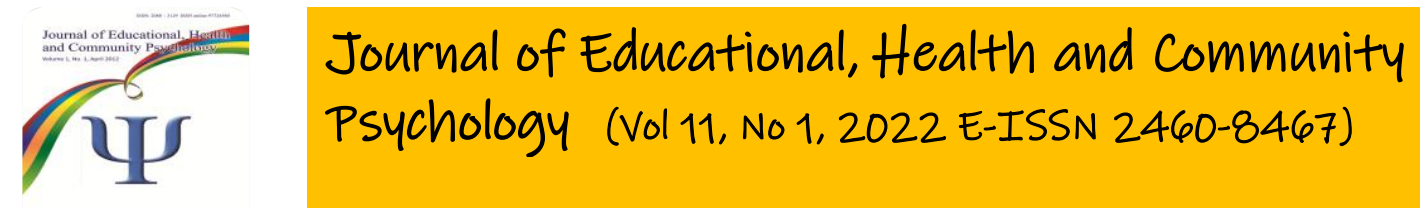

Rasyida, Rahayu, Aprodita.

202I). In addition, the level of IU in individuals was found to have a significant negative correlation with resilience, whereas individuals with high levels of IU tend to have low levels of resilience (Karatas \& Tagay, 2021).

The results of the different tests showed a significant difference between the IU scores of males and females, with the average IU stay in the female group being higher than that of the male group. This finding means that females experience more worry than males. The results of this study support the research of Parlapani et al. (2020) and Yeler, Berber, Ozdogan, \& Cok (202I), which showed that females had higher IU levels than males. In addition, research by Robichaud, Dugas, and Conway (2003) found that worry scores in females significantly predict IU, negative problem orientation, positive belief about worry, and cognitive avoidance. Parlapani et al. (2020) explained that this difference reflects the assessment of threats made by females regarding unpredictable situations and a greater desire for predictable situations than males.

The results of the second difference test were carried out to examine whether there are differences in the level of IU associated with socio-economic factors. Socio-economic factors are related to how a person's financial condition, work, and social status in society. The difference tests conducted on the participants' socio-economic factors showed significant differences between the lower, middle, and upper socio-economic status groups, especially in the lower and middle socio-economic status groups. Individuals with lower socio-economic status are likely to face more frequent and intense situations of uncertainty. As a result, they are more sensitive to uncertain situations and become less confident in dealing with them than individuals with upper socio-economic status (Yang et al., 20l7).

\section{Limitation}

This study has several limitations related to the characteristics of the research sample that will affect the interpretation of the results of this study. The sample in this study had an unbalanced proportion of the group. The number of female respondents is more than male respondents; therefore, the generalizability of the findings of this study for the male group can be considered less representative. Similarly, the group 

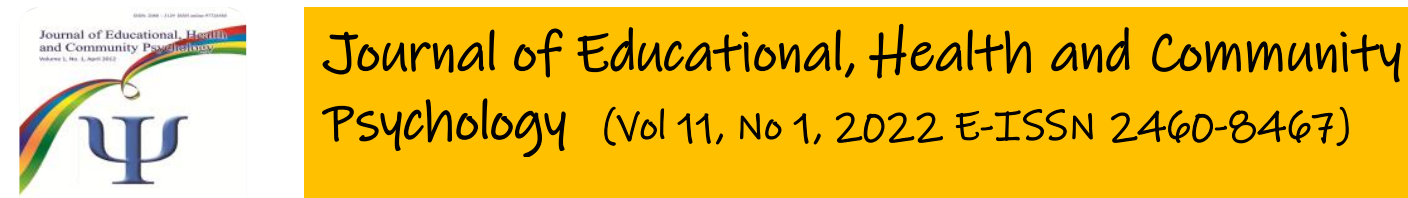

Rasyida, Rahayu, Aprodita.

of respondents from the lower and high socio-economic status is not proportional to the number of respondents from the middle socio-economic status. In addition, this study aims to describe the level of IU in employees during the pandemic. However, the respondents' work in this study has not explored the variations in Work from Home and Work from Office policies that are different for each job. Each of these groups may face different conditions of uncertainty. If this is known, then the interpretation of the research results can be reviewed deeper.

Further research on a similar population can be directed to examine the association of IU with other variables such as job insecurity, work-related distress, and fear of COVID-19. Thus, a broader understanding will be obtained regarding the dynamics of employees' psychological conditions related to concerns during the COVID-19 pandemic.

\section{Conclusion}

This study used descriptive analysis to describe the level of IU in workers during the COVID-I9 pandemic. The results showed that the IU of the respondents in this study tended to be below. However, there are still some research respondents who have a relatively high level of IU. In addition, this study also showed differences between IU levels for males and females, and there are differences between IU levels in the lower and middle socio-economic groups. Individuals with high levels of IU need to pay special attention to the impact of their worries so they do not develop into more serious psychological conditions. The COVID-19 pandemic has brought various uncertain situations that employees and companies need to deal with. Companies need to adapt and adjust more quickly to face changes and crises such as this one. This also needs to be followed by decision-making firmly and based on clear considerations so that employees can anticipate various changes that may occur and reduce the uncertainty faced in their work environment. In addition, companies need to provide or develop Employee Assistance Programs that can help identify employee problems. 


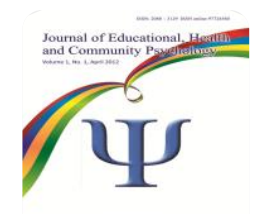

Journal of Educational, Health and Community

Psychology (Vol 11, No 1, 2022 E-ISSN 2460-8467)

Rasyida,

Rahayu,

Aprodita.

\section{References}

Aprodita, N. (202I). Peran intolerance of uncertainty terhadap depresi pada individu dewasa awal. Humanitas (Jurnal Psikologi), 5(2), 179 - 196. https://doi.org/10.28932/humanitas.

Asmundson, G. J. G., Michelle, M. P., Landry, C. A., Rachor, G. S., Mckay, D., Taylor, S. (2020). Do preexisting anxiety-related and mood disorders differentially impact COVID- 19 stress response and coping? Journal of Anxiety Disorders, 74. https://doi.org/10.1016/j.janxdis.2020.10227I

Bakioğlu, F., Korkmaz, O., \& Ercan, H. (2020). Fear of COVID-I9 and positivity: Mediating role of Intolerance of uncertainty, depression, anxiety, and stress. International Journal of Mental Health and Addiction. https://doi.org/ 10.1007/s I |469-020-0033|-y

Blanuša, J., Barzut, V., \& Knežević, J. (202I). Intolerance of uncertainty and fear of covid-19 moderating role in the relationship between job insecurity and work-related distress in the Republic of Serbia. Frontiers in Psychology, I 2(June). https://doi.org//0.3389/fpsyg. I.647972.

Buhr, K., \& Dugas, M. J. (2002). The Intolerance of uncertainty scale: psychometric properties of the English version. Behaviour Research and Therapy, 40(8), 931-945.

Chen, S., Yao, N., \& Qian, M. (2018). The influence of uncertainty and Intolerance of uncertainty on anxiety. Journal of Behavior Therapy and Experimental Psychiatry, 6I, 60-65. https://doi.org/10.1016/j.jbtep.2018.06.005

Dugas, M. J., Gagnon, F., Ladouceur, R., \& Freeston, M. H. (1998). Generalized anxiety disorder: a preliminary test of a conceptual model. Behaviour Research and Therapy, 36(2), 215-226. https://doi.org/10.1016/S0005-7967(97)00070-3

Dugas, M. J., Gosselin, P., \& Ladouceur, R. (200I). Intolerance of uncertainty and worry: Investigating specificity in a non-clinical sample. Cognitive Therapy and Research, 25(5), 55I-558. https://doi.org/|10.1023/A:I0055534|4688

Freeston, M., Tiplady, A., Mawn, L., Bottesi, G, \& Thwaites, S. (2020). Towards a model of uncertainty distress in the context of coronavirus (COVID-19). The Cognitive Behaviour Therapist, 13. https://doi.org/I0.1017/SI754470X2000029X

Godinic, O., \& Khudaykulov. (2019). Effects of economic uncertainty on mental health in the covid-19 pandemic context: social identity disturbance, job uncertainty, and psychological well-being model. International Journal of Innovation and Economic Development Vol 6 (I), 6I-74. DOI: I0.18775/ijied. I849-755 I-7020.20I5.6I.2005

Gu, Y., Gu, S., Lei, Y., \& Li, H. (2020). From uncertainty to anxiety: How uncertainty fuels anxiety in a process mediated by Intolerance of uncertainty. Neural Plasticity. https://doi.org/l0.1155/2020/8866386 


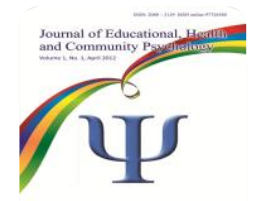

Karatas, Z. \& Tagay, O. (202I). The relationships between the resilience of the adults affected by the covid pandemic in Turkey and Covid-19 fear, meaning in life, life satisfaction, Intolerance of uncertainty, and hope. Personality and individual differences, 172. https://doi.org/10.1016/j.paid.2020.110592

Kemnaker. (2020). Menaker: Badai pasti berlalu, panggil kembali pekerja yang ter-PHK nanti. diakses tanggal 2I Agustus 202I. https://www.kemnaker.go.id/news/detail/menaker-badai-pasti-berlalupanggil-kembali-pekerja-yang-ter-phk-nanti,).

Ladouceur, R., Gosselin, P., \& Dugas, M. J. (2000). Experimental manipulation of intolerance of uncertainty: a Study of a theoretical model of worry. Behav Res Ther 38(9):933-4I. DOI: 10.1016/s0005-7967(99)00I33-3. PMID: I0957827.

Nekic, M. \& Mamic, S. (2019). Intolerance of uncertainty and mindfulness as determinants of anxiety and depression in female students. Behavioral Sciences, 9, I35-I4I.

Parlapani, E., Holeva, V., Nikopoulou, V. A., Sereslis, K., Athanasiadou, M., Godosidis, A., Stephanou, T., \& Diakogiannis, I. (2020). Intolerance of uncertainty and loneliness in older adults during the COVID-19 pandemic. Frontiers in Psychiatry, II(August), I-I2. https://doi.org// 0.3389/fpsyt.2020.00842

Pepperdine, E., Lomax, C., \& Freeston, M. H. (20I8). Disentangling Intolerance of uncertainty and threat appraisal in everyday situations. Journal of Anxiety Disorders, 57, 31-38. https://doi.org/10.1016/J.JANXDIS.2018.04.002

Rahmadiani, N. D., \& Hartatik, F. Y. (2019). Intolerance of uncertainty as a mediator between psychological flexibility and future anxiety among vocational high school students. 7(I). https://doi.org/10.25215/0701.055

Robichaud, M., Dugas, M. J., \& Conway, M. (2003). Gender differences in worry and associated cognitivebehavioral variables. Journal of Anxiety Disorders, I7(5), 50I-5/6. doi:10.1016/s08876185(02)00237-2

Satuan Tugas Penanganan Covid 19. (2020). Apa itu pembatasan sosial berskala besar (PSBB)?. https://covid 19.go.id/edukasi/masyarakat-umum/apa-itu-pembatasan-sosial-berskala-besar-psbb

Satuan Tugas Penanganan Covid 19. (2021). Peta sebaran covid. https://covid/9.go.id/peta-sebarancovid I9

Saulnier, K. G., Allan, N. P., Raines, A. M., \& Schmidt, N. B. (2019). Depression and Intolerance of uncertainty: relations between uncertainty subfactors and depression dimensions. Psychiatry, 82(I), 72-79.

Sexton, K. A. \& Dugas, M. J. (2009). Defining distinct negative beliefs about uncertainty: Validating the factor structure of the Intolerance of uncertainty scale. Psychological Assessment, 2 I (2), I76-I86. 


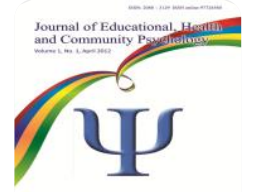

Journal of Educational, Health and Community

Psychology (Vol 11, No 1, 2022 E-ISSN 2460-8467)

Rasyida,

Rahayu,

Aprodita.

Taha, S., Matheson, K., Cronin, T., \& Anisman, H. (20I4), Intolerance of uncertainty, appraisals, coping, and anxiety: The case of the $2009 \mathrm{HINI}$ pandemic. Br J Health Psychol, 19: 592-605. https://doi.org/10.1 I I I/bjhp.12058

Valle, M. V. Del, Andrés, M. L., Urquijo, S., Yerro-Avincetto, M., López-Morales, H., \& Canet-Juric, L. (2020). Intolerance of uncertainty over COVID-19 pandemic and its effect on anxiety and depressive symptoms. Interamerican Journal of Psychology, 54(2), I-17. https://doi.org// 0.30849/ripijp.v54i2.1335.

Widhiarso, W. (20I4). Pengategorian data dengan menggunakan statistik hipotetik dan statistik empirik. Fakultas Psikologi. Universitas Gajah Mada., I-3. http://widhiarso.staff.ugm.ac.id/wp/wpcontent/uploads/Widhiarso-Pengategorian-Data-dengan-Menggunakan-Statistik-Hipotetik-danStatistik-Empirik.pdf

Yang, T., Yang, X. Y., Yu, L., Cottrell, R. R., \& Jiang, S. (2017). Individual and regional association between socio-economic status and uncertainty stress, and life stress: a representative nationwide study of China. International Journal for Equity in Health, I6. DOI I0.1/86/s I2939017-0618-7

Yeler, Z., Berber, K., Özdoğan, H. K., \& Çok, F. (202I). Quarter Life Crisis among Emerging Adults in Turkey and Its Relationship with Intolerance of Uncertainty. Turkish Psychological Counseling and Guidance Journal, I I (6I), 245-262.

Yuniardi, M. (2020). Should we shoot Intolerance of uncertainty for anxiety disorders? Data from the UK and Indonesia. International Journal of Psychosocial Rehabilitation, 24(08), 5I34-5I46. https://doi.org// 0.37200/IJPR/V24I8/PR280524

Zhuo, L., Wu, Q., Le, H., Li, H., Zheng, L., Ma, G., \& Tao, H. (202I). COVID-I9-related Intolerance of uncertainty and mental health among back-to-school students in Wuhan: The Moderation Effect of Social Support. International journal of environmental research and public health, I8(3), 98I. https://doi.org//0.3390/ijerph I 803098 I 